\title{
HIV and Food Insecurity: A Syndemic Amid the COVID-19 Pandemic
}

\author{
Taylor McLinden $^{1} \cdot$ Sofia Stover ${ }^{2} \cdot$ Robert S. Hogg $^{1,3}$
}

Published online: 8 May 2020

(c) Springer Science+Business Media, LLC, part of Springer Nature 2020

On February 1, 2020, approximately 1 month after cases of pneumonia of unknown cause were detected in Wuhan, China [1], an editorial titled 'The syndemic threat of food insecurity and HIV' was published in The Lancet HIV [2]. In this publication, the authors conclude that advances in the fight against HIV must not be undermined by an experience as fundamental as food insecurity. In the following month, coronavirus disease 2019 (COVID-19), an infection caused by severe acute respiratory syndrome coronavirus 2 (SARS-CoV-2), was declared a pandemic by the World Health Organization [3].

While the authors of this editorial did not have the opportunity to reflect on the impacts of COVID-19 on the HIVfood insecurity syndemic, they discussed a 'severe economic situation' in Zimbabwe that 'has left the healthcare system in a dire state, and spiralling inflation has left many without the money to pay for food let alone basic health services' [2]. While this statement reflects a difficult reality for people living with HIV (PLWH) in Zimbabwe, it is anticipated that there will be challenging economic situations ahead, for many countries, as a result of the COVID-19 pandemic $[4,5]$. As such, it is not surprising that food insecurity has already been highlighted in a syndemic conceptualization of HIV and COVID-19 among PLWH [6].

In addition to the health [7] and social [8,9] impacts, the economic impacts of COVID-19, at both the micro- and macro-levels, have been unprecedented: long-standing businesses are shuttering $[4,5]$, unemployment levels are climbing [10], and some countries are now reporting shrinking economies in Quarter 1, 2020 for the first time in more than

Taylor McLinden

tmclinden@cfenet.ubc.ca

1 British Columbia Centre for Excellence in HIV/AIDS, Vancouver, Canada

2 Facultad de Medicina, Universidad de Buenos Aires, Buenos Aires, Argentina

3 Faculty of Health Sciences, Simon Fraser University, Burnaby, Canada a decade [11-13]. For example, in March 2020, Statistics Canada reported that more than one million jobs were lost in Canada, the worst single-month change on record [14]. Similarly, a recent United States Department of Labor News Release (April 16, 2020) highlighted that several million Americans are now filing for unemployment insurance each week [15]. While it has yet to be quantified, the experience of food insecurity, along with its consequences, will potentially be exacerbated for vulnerable populations, including PLWH, during these turbulent times.

\section{Food Security: A Basic Human Right}

According to the Universal Declaration of Human Rights [16], access to adequate food is considered a basic human right. An intrinsic precursor to this right is food security. Lack of food security, or food insecurity, exists "whenever the availability of nutritionally adequate and safe foods or the ability to acquire acceptable foods in socially acceptable ways is limited or uncertain' [17]. Central to the concept of food insecurity is the focus on uncertain or inadequate food access due to limited financial resources [18]. As such, any events that impact one's ability to acquire financial resources may, potentially, increase their risk of experiencing food insecurity.

"Everything we know about household food insecurity in Canada suggests that without effective responses to the hardships brought on by COVID-19, food insecurity will increase in prevalence and severity, and the health implications of being food insecure will become even more dire."

- Dr. Valerie Tarasuk (PROOF-Food Insecurity Policy Research, Canada) [19]

Food insecurity, a social determinant of health [20], is a dimension of nutritional vulnerability [21]. Therefore, as a result of the deprivation that underlies the experience of food insecurity, it is a public health issue [22] and a matter for social action [21, 23]. In terms of the immediate impacts 
of COVID-19 on food insecurity, there have been recent news reports, in both Canada [24] and the United States [25], highlighting dramatic increases in food bank usage. Acknowledging that food banks are, in fact, limited in their capacity to address the root causes of food insecurity [26, 27], their utility in acting as a 'canary in a coal mine' [28] should serve as a warning sign for us all.

\section{Food Insecurity Among People Living with HIV}

Among PLWH, the existing body of food insecurity-related literature is diverse and rigorous. Numerous studies have been completed in a variety of settings, providing food insecurity prevalence estimates as well as descriptions of consequences of food insecurity [29]. From this work, it is understood that there are consistently high prevalences of food insecurity, particularly severe food insecurity, among PLWH [30-32]. Importantly, food insecurity prevalence estimates among PLWH are, almost universally, higher than those found in comparable general population samples [33-35]. Although comparability is limited by differences in the tools used to measure food insecurity [36], the overwhelming occurrence of this experience among PLWH has resulted in researchers describing the HIV-food insecurity relationship as a 'vicious cycle' that must be addressed [30-32].

In addition, several systematic reviews have linked food insecurity with outcomes that are important among PLWH; food insecurity is associated with lower CD4 cell counts [37], incomplete HIV viral load suppression [38], and suboptimal HIV treatment adherence [39]. Therefore, while the experience of food insecurity is a cause for concern regardless of the setting [34, 35], there are, indeed, HIVspecific implications to consider [32]. Subsequently, intending to inform interventions to reduce food insecurity among PLWH, several studies have also examined risk factors for this experience [29]. In addition to behavioural and clinical factors, such as illicit substance use [40, 41] and depressive symptoms [41, 42] (both of which may be exacerbated by the COVID-19 pandemic [6]), socioeconomic factors, such as low income and unemployment, are consistently identified as important risk factors for food insecurity among PLWH [41-43].

\section{Policy Interventions in Response to COVID-19}

During a time when the economic impacts $[4,5]$ of a pandemic may be propagating the HIV-food insecurity syndemic [6], it is important to reinforce the idea that food assistance, whether it be from food banks or elsewhere, is not necessarily targeting the drivers of food insecurity [44, 45]. In other words, if the goal of risk factor epidemiology is to identify unbiased associations, or causes of outcomes, and to intervene on such causes [46], the provision of food does not necessarily act on these determinants (e.g., illicit substance use, depressive symptoms, low income, unemployment [40-43]). While we certainly do not discourage the provision of food as a form of harm reduction [47], the historic policy actions being taken, in response to COVID-19, may provide an opportunity to better understand potential solutions to food insecurity.

For example, researchers have previously used the introduction of a 'Universal Child Care Benefit' in 2006 to estimate the effect of income supplementation on food insecurity in Canada's general population [48]; this was a policy that provided parents with $\$ 100$, per month, for each child aged less than 6 years. Treating the implementation of the policy as a 'natural experiment' [49], it was found that a relatively small monthly income supplement led to reductions in food insecurity, with larger reductions in vulnerable sub-groups. A more recent study [50], using the same difference-in-differences methodology, examined a similar policy; severe food insecurity declined among Canadian families who received the income supplement. Other food insecurity-related publications have evaluated similar interventions [51-53], further contributing to the expanding evidence-base in this area.

In response to COVID-19, the Government of Canada announced a 'Canada Emergency Response Benefit' on March 25, 2020 [54]. This taxable benefit provides $\$ 2000$ per month, for up to 4 months, to Canadian's suffering losses of income during the pandemic. Around the same time, the White House unveiled a two-trillion-dollar relief package within their 'Coronavirus Aid, Relief and Economic Security (CARES)' Act [55]. While these are limited examples from two North American countries, they serve to highlight an opportunity for researchers to carefully unpack these policies, and others like them, to determine if their impacts on food insecurity can be evaluated. It is important to note, however, that several assumptions are necessary when attempting to quantify the effects of policies (e.g., the parallel trends assumption when using the differencein-differences method) [56, 57]. As such, findings should be presented alongside sensitivity analyses and robustness checks [56].

\section{Conclusions}

The health [7], social [8, 9], and economic $[4,5,10]$ impacts of COVID-19 may interfere with the availability of nutritionally adequate and safe foods as well as the ability for people, including PLWH, to acquire food in socially acceptable 
ways. As indicated by reports of increasing food bank usage $[24,25]$, it is reasonable to suggest that food insecurity among PLWH, along with its consequences (i.e., lower CD4 cell counts [37], incomplete HIV viral load suppression [38], and sub-optimal HIV treatment adherence [39]), may become more common. While decision makers, PLWH, and their caregivers need to acknowledge this potential reality, it may also be an opportunity for HIV researchers to study the impacts of COVID-19-related policy implementations on food insecurity.

\section{References}

1. World Health Organization. Pneumonia of unknown cause - China (Disease outbreak news) 2020 [Available from: https://www.who. int/csr/don/05-january-2020-pneumonia-of-unkown-cause-china/ en/.

2. The Lancet HIV. The syndemic threat of food insecurity and HIV. Lancet HIV. 2020;7(2):75.

3. World Health Organization. WHO Director-General's opening remarks at the media briefing on COVID-19 (11 March 2020) 2020 [Available from: https://www.who.int/dg/speeches/detail/ who-director-general-s-opening-remarks-at-the-media-briefingon-covid-19---11-march-2020.

4. Fernandes N. Economic Effects of Coronavirus Outbreak (COVID-19) on the World Economy (March 22, 2020): Social Science Research Network (SSRN); 2020 [Available from: https ://papers.ssrn.com/sol3/papers.cfm?abstract_id=3557504.

5. Barua S. Understanding Coronanomics: The Economic Implications of the Coronavirus (COVID-19) Pandemic (April 1, 2020): Social Science Research Network (SSRN); 2020 [Available from: https://papers.ssrn.com/sol3/papers.cfm?abstract_id=3566477.

6. Shiau S, Krause KD, Valera P, Swaminathan S, Halkitis PN. The Burden of COVID-19 in People Living with HIV: A Syndemic Perspective. AIDS Behav. 2020.

7. Guan WJ, Ni ZY, Hu Y, Liang WH, Ou CQ, He JX, et al. Clinical Characteristics of Coronavirus Disease 2019 in China. N Engl J Med. 2020;382(18):1708-20.

8. Hall KS, Samari G, Garbers S, Casey SE, Diallo DD, Orcutt M, et al. Centring sexual and reproductive health and justice in the global COVID-19 response. Lancet. 2020;395(10231):1175-7.

9. Marziali ME, Card KG, McLinden T, Wang L, Trigg J, Hogg RS. Physical distancing in COVID-19 may exacerbate experiences of social isolation among people living with HIV. AIDS Behav. 2020.

10. Coibion O, Gorodnichenko, Y, Weber, M. Labor Markets During the COVID-19 Crisis: A Preliminary View (April 11, 2020). Chicago Booth Paper No. 20-06: Social Science Research Network (SSRN); 2020 [Available from: https://papers.ssrn.com/sol3/Paper s.cfm?abstract_id=3574736.

11. BBC News (Business). China's virus-hit economy shrinks for first time in decades (April 17, 2020) 2020 [Available from: https:// www.bbc.com/news/business-52319936.

12. Bloomberg (Sam Kim). South Korea's Economy Shrinks the Most Since 2008 (April 22, 2020) 2020 [Available from: https://www. bloomberg.com/news/articles/2020-04-22/south-korea-s-econo my-shrinks-most-since-2008-amid-pandemic.

13. Bloomberg (Iain Rogers). German Economy Seen Shrinking $10 \%$ This Quarter Due to Virus 2020 [Available from: https://www. bloomberg.com/news/articles/2020-04-08/german-institutes-see4-2-contraction-in-2020-then-big-rebound.
14. Statistics Canada. Labour Force Survey, March 20202020 [Available from: https://www150.statcan.gc.ca/n1/daily-quoti dien/200409/dq200409a-eng.htm.

15. United States Department of Labor. News Release (April 16, 2020): The COVID-19 virus continues to impact the number of initial claims and insured unemployment. 2020 [Available from: https://oui.doleta.gov/press/2020/041620.pdf.

16. United Nations. Universal Declaration of Human Rights. Paris: France; 1948.

17. Anderson SA. Core indicators of nutritional state for difficult to sample populations. J Nutr. 1990;120(11):1559S-600S.

18. Health Canada. Canadian Community Health Survey, Cycle 2.2, Nutrition (2004): Income-Related Household Food Security in Canada 2004 [Available from: https://www.canada.ca/content/ dam/hc-sc/migration/hc-sc/fn-an/alt_formats/hpfb-dgpsa/pdf/ surveill/income_food_sec-sec_alim-eng.pdf.

19. Tarasuk V. Food insecurity and COVID-19 (Food Secure Canada): PROOF - Food Insecurity Policy Research; 2020 [Available from: https://foodsecurecanada.org/sites/foodsecurecanada.org/files/ proof-fsc_webinar_mar_26_2020.pdf.

20. Raphael D. Social Determinants of Health: Canadian Perspectives. Toronto: Canadian Scholars' Press Inc; 2009.

21. Tarasuk V. Discussion Paper on Household and Individual Food Insecurity. 2001.

22. Rideout K, Kosatsky T. Food insecurity: A public health issue for BC. B C Med J. 2014;56(1):29.

23. Roncarolo F, Potvin L. Food insecurity as a symptom of a social disease. Can Fam Physician. 2016;62:291-2.

24. Global News (Beatrice Britneff). Food banks' demand surges amid COVID-19. Now they worry about long-term pressures (April 15, 2020) 2020 [Available from: https://globalnews.ca/news/6816023/ food-bank-demand-covid-19-long-term-worry/.

25. NBC News (Kenzi Abou-Sabe CR, Cynthia McFadden, Jaime Longoria). COVID-19 crisis heaps pressure on nation's food banks (April 7, 2020) 2020 [Available from: https://www.nbcne ws.com/news/us-news/covid-19-crisis-heaps-pressure-nation-sfood-banks-n1178731.

26. Kirkpatrick SI, Tarasuk V. Food Insecurity and Participation in Community Food Programs among Low-income Toronto Families. Can J Public Health. 2009;100(2):135-9.

27. Bazerghi C, McKay FH, Dunn M. The role of food banks in addressing food insecurity: a systematic review. J Community Health. 2016;41(4):732-40.

28. Toronto Star (Laurie Monsebraaten). Jump in food bank use called 'canary in the coal mine' 2019 [Available from: https://www.thest ar.com/news/gta/2019/11/04/jump-in-food-bank-use-called-canar y-in-the-coal-mine.html.

29. McLinden T. Injection drug use and food insecurity among HIVhepatitis $\mathrm{C}$ virus co-infected individuals: associations, mechanisms, and interventions (Chapter 2: Literature review - 2.5 Food insecurity in HIV-positive populations): McGill University ( $\mathrm{PhD}$ Thesis); 2018.

30. Frega R, Duffy F, Rawat R, Grede N. Food insecurity in the context of HIV/AIDS: a framework for a new era of programming. Food Nutr Bull. 2010;31(4):S292-312.

31. Anema A, Vogenthaler N, Frongillo E, Kadiyala S, Weiser S. Food insecurity and HIV/AIDS: current knowledge, gaps, and research priorities. Curr HIV/AIDS Rep. 2009;6:224-31.

32. Weiser SD, Young SL, Cohen CR, Kushel MB, Tsai AC, Tien PC, et al. Conceptual framework for understanding the bidirectional links between food insecurity and HIV/AIDS. Am J Clin Nutr. 2011;94(6):1729S-39S.

33. Food and Agriculture Organization of the United Nations. Regional Overview of Food Security and Nutrition in Africa 2016 - the challenges of building resilience to shocks and stresses. 2017. 
34. Tarasuk V, Mitchell A. Household food insecurity in Canada, 2017-18. Toronto: Research to identify policy options to reduce food insecurity (PROOF); 2020.

35. Coleman-Jensen A, Rabbitt MP, Gregory CA, Singh A. A report summary from the Economic Research Service-Household Food Security in the United States in 2016. 2017.

36. Jones AD, Ngure FM, Pelto G, Young SL. What are we assessing when we measure food security? A compendium and review of current metrics. Adv Nutr. 2013;4(5):481-505.

37. Aibibula W, Cox J, Hamelin AM, Mamiya H, Klein MB, Brassard P. Food insecurity and low CD4 count among HIV-infected people: a systematic review and meta-analysis. AIDS Care. 2016;28(12):1577-85.

38. Aibibula W, Cox J, Hamelin AM, McLinden T, Klein MB, Brassard P. Association between food insecurity and HIV viral suppression: a systematic review and meta-analysis. AIDS Behav. 2017;21(3):754-65.

39. Singer AW, Weiser SD, McCoy SI. Does Food Insecurity Undermine Adherence to Antiretroviral Therapy? A Systematic Review. AIDS Behav. 2015;19(8):1510-26.

40. McLinden T, Moodie EEM, Harper S, Hamelin AM, Anema A, Aibibula W, et al. Injection drug use, food insecurity, and HIVHCV co-infection: a longitudinal cohort analysis. AIDS Care. 2018;30(10):1322-8.

41. Anema A, Weiser SD, Fernandes KA, Ding E, Brandson EK, Palmer A, et al. High prevalence of food insecurity among HIVinfected individuals receiving HAART in a resource-rich setting. AIDS Care. 2011;23(2):221-30.

42. Cox J, Hamelin AM, McLinden T, Moodie EE, Anema A, RolletKurhajec $\mathrm{KC}$, et al. Food Insecurity in HIV-Hepatitis C Virus Coinfected Individuals in Canada: the Importance of Co-morbidities. AIDS Behav. 2017;21(3):792-802

43. Normén L, Chan K, Braitstein P, Anema A, Bondy G, Montaner JS, et al. Food insecurity and hunger are prevalent among HIV-positive individuals in British Columbia. Canada. J Nutr. 2005;135(4):820-5.

44. Tarasuk V. A critical examination of community-based responses to household food insecurity in Canada. Health Educ Behav. 2001;28(4):487-99.

45. Tarasuk VD, Davis B. Responses to food insecurity in the changing Canadian Welfare State. J Nutr Educ. 1996;28(2):71-5.

46. Rothman KJ, Greenland S. Causation and causal inference in epidemiology. Am J Public Health. 2005;95(Suppl 1):S144-50.

47. Miewald C, McCann E, McIntosh A, Temenos C. Food as harm reduction: barriers, strategies, and opportunities at the intersection of nutrition and drug-related harm. Crit Public Health. 2017;28(2):71-5.
48. Ionescu-Ittu R, Glymour MM, Kaufman JS. A difference-in-differences approach to estimate the effect of income-supplementation on food insecurity. Prev Med. 2015;70:108-16.

49. Craig P, Katikireddi SV, Leyland A, Popham F. Natural experiments: an overview of methods, approaches, and contributions to public health intervention research. Annu Rev Public Health. 2017;38:39-56.

50. Brown EM, Tarasuk V. Money speaks: reductions in severe food insecurity follow the Canada Child Benefit. Prev Med. 2019;129:105876.

51. Loopstra R, Reeves A, McKee M, Stuckler D. Food insecurity and social protection in Europe: quasi-natural experiment of Europe's great recessions 2004-2012. Prev Med. 2016;89:44-50.

52. Li N, Dachner N, Tarasuk V. The impact of changes in social policies on household food insecurity in British Columbia, 20052012. Prev Med. 2016;93:151-8.

53. Loopstra R, Dachner N, Tarasuk V. An exploration of the unprecedented decline in the prevalence of household food insecurity in Newfoundland and Labrador, 2007-2012. Can Public Policy. 2015;41(3):191-206.

54. Department of Finance (Government of Canada). Government introduces Canada Emergency Response Benefit to help workers and businesses (March 25, 2020) 2020 [Available from: https:// www.canada.ca/en/department-finance/news/2020/03/introduces -canada-emergency-response-benefit-to-help-workers-and-busin esses.html.

55. The White House (United States of America). President Donald J. Trump Is Providing Economic Relief to American Workers, Families, and Businesses Impacted by the Coronavirus 2020 [Available from: https://www.whitehouse.gov/briefings-statements/presi dent-donald-j-trump-providing-economic-relief-american-worke rs-families-businesses-impacted-coronavirus/.

56. Wing C, Simon K, Bello-Gomez RA. Designing difference in difference studies: best practices for public health policy research. Annu Rev Public Health. 2018;39:453-69.

57. Dimick JB, Ryan AM. Methods for evaluating changes in health care policy: the difference-in-differences approach. JAMA. 2014;312(22):2401-2.

Publisher's Note Springer Nature remains neutral with regard to jurisdictional claims in published maps and institutional affiliations. 